\title{
Economic value and exploiting approaches of sea asparagus, a seawater-irrigated vegetable
}

\author{
Litian Feng ${ }^{1,2^{*}}$, Bin $\mathrm{Ji}^{3}$, Bin $\mathrm{Su}^{2}$ \\ ${ }^{1}$ Jinan Winsir Biotechnology Co., Ltd., Jinan, China; *Corresponding Author: fenglt2004@sina.com \\ ${ }^{2}$ Shandong Seawater Vegetable Biotechnology Development Co. Ltd., Jinan, China \\ ${ }^{3}$ Department of Ecological Science, Faculty of Earth and Life Sciences, VU University Amsterdam, The Netherlands
}

Received August 2013

\begin{abstract}
Sea asparagus is a newly emerging seawater-irrigated vegetable. Firstly, the economic value of sea asparagus was introduced, and then, some exploiting approaches of sea asparagus were fully reviewed. The exploiting approaches mainly include fresh vegetable, pickle, bio-salt, healthcare products, animal feed, vegetable oil, biodiesel and skin-care products.
\end{abstract}

Keywords: Sea Asparagus; Seawater-Irrigated Vegetable; Economic Value; Exploiting Approaches; Bio-Salt

\section{INTRODUCTION}

Seawater-irrigated vegetables are newly emerging vegetable varieties of the world's agriculture industry. After many years of screening, domestication and breeding research and with modern biotechnologies, scientists have accomplished selecting halophytes with inherently high salinity tolerance for use as crop plants, and breeding them to new cultivars with good taste and rich nutrition for human food. Not only can these varieties of vegetables be irrigated directly with seawater, but also they contain rich nutrients and have unique health benefits for human beings [1-5]. Seawater-irrigated vegetables can endure high salinity, which means they are suitable to grow on salt marshes, saline wasteland and desert, and they can be irrigated with full-strength sea-water. Therefore, it is a significant solution in agriculture in terms of saving fresh water and turning barren land into arable land.

Growing crops directly with full-strength seawater on saline wastelands for human food resources has been a fancy dream of mankind for a long time, and it has also been an aim for scientists to accomplish. The emergence of seawater-irrigated vegetables is a milestone for the development of the seawater-irrigated agriculture in the world.

In recent years, sea asparagus, a seawater-irrigated vegetable, which is suitable to grow on coastal deserts and saline land, is gradually applied in agriculture industry worldwide. This new seawater-irrigated vegetable has already been applied for human food in many countries, such as the United States, Mexico, the Netherlands, Saudi Arabia, Egypt, Israel, Eritrea, Australia, Canada, New Zealand, South Korea, Japan and China [5-7].

\section{COMMON NAMES AND BIOLOGICAL ORIGIN OF SEA ASPARAGUS}

Sea asparagus has many common names. It is respectively called glasswort, saltwort, pickle weed, sea bean, sea ginseng, samphire or marsh samphire in different countries and places [7].

Sea asparagus originated from halophyte and its scientific name is Salicornia spp. According to the literature, the genus of Salicornia belongs to the Chenopodiaceae family or the Amaranthaceae family and is comprised of 25 to 30 species. It is dicotyledonous and herbaceous annual and has articulated succulent and cylindrical stems. In the later stages of growth, the plant appears leafless and its stem turns woody. Plant height is 30 - $90 \mathrm{~cm}$. The color of the plant is green or purple. The flowers are sessile and mostly arranged in 3-flowered cymes per bract. The bracts are opposite, connate and the flowers are tightly embedded in cavities of the main axis and partly hidden by the bracts $[8,9]$.

\section{ECONOMIC VALUE OF SEA ASPARAGUS}

Sea asparagus has a unique salty flavor, with vividly deep green color and beautiful coral-like shape and crisp taste. Since sea asparagus can be grown on saline marsh land and irrigated with seawater, it can dramatically reduce the chances of catching diseases. Therefore growing sea asparagus can avoid using pesticides and fertilizers. It can meet the requirements of organic vegetable 
producing process, since it is domesticated from wild salt-tolerant plants without gene modification. The whole growing process is eco-safe and organic [7].

\subsection{Nutrient Composition of Sea Asparagus}

The nutrients of sea asparagus includes at least protein, amino acids, $\beta$-carotene, vitamins (vitamin $\mathrm{C}$, vitamin $\mathrm{B} 1$, etc.), marine mineral and trace elements (sodium, potas-sium, calcium, magnesium, phosphorus, iron, zinc, manganese, iodine, selenium, etc.) and a number of biologically active substances (polysaccharides, alkaloids, etc.) $[6,7]$.

\subsection{Herbal and Therapeutic Value of Sea Asparagus}

Sea asparagus not only can be used as a unique vegetable for food consumption, it has been an herbal medicine as well. According to the literature and folk remedies, it has been believed, for a long history, that Sea asparagus shows effects on curing obesity, hypertension, constipation, diabetes, asthma, arthritis, sepsis and cancer. In recent years, with the fact that sea asparagus has been increasingly cultivated worldwide, people start to pay close attention to the medicinal and nutritional value of sea asparagus. Many studies on nutritional and medicinal mechanisms of sea asparagus have been carried out. Up to now, the herbal and therapeutic value of sea asparagus has been scientifically proven. It is effective to strengthen the immune system, diminish inflammation and prevent atherosclerosis, hypertension and tumors. In addition to having effects on anti-oxidation and an-tiaging, sea asparagus also shows effects on weight loss and skin whitening [10-25].

\subsection{Growing Sea Asparagus as an Oilseed Crop in Tropical and Subtropical Areas}

In tropical and subtropical regions, sea asparagus is an oil crop that can be irrigated with full-strength seawater. Its seeds are rich in oil, oil content of the seed ranges from $26 \%$ to $33 \%$. The polyunsaturated fatty acids of the seed oil account for more than $90 \%$ of the total fatty acids and particularly the percentage of linoleic acid in the total fatty acids is nearly $70 \%$. Up to now, the best species of Salicornia spp. as an oilseed crop is Salcornia bigelovii [1,3].

The seed oil of sea asparagus is rich in linoleic acid, an essential fatty acid of human body that has important physiological functions. The linoleic acid cannot be produced naturally within the body, and it must be absorbed by food intake. The seed oil also contains relatively high linolenic acid, which is the precursor of body prostaglandin synthesis. Therefore, the seed oil of sea asparagus is an ideal healthy vegetable oil, compared with the traditional vegetable oils. It has excellent an-ti-oxidation and anti-aging functions $[1,7,26]$.

\section{EXPLOITING APPROACHES OF SEA ASPARAGUS}

Despite growing sea asparagus as a new sea-water-irrigated vegetable has already gradually been applied worldwide, unfortunately until now, it is still in the early stage of its agriculture industry development. The main reasons of sea asparagus not having been cultivated in large scale at present are: first, consumers have limited knowledge of consuming sea asparagus as a vegetable; second, sea asparagus is a seasonal vegetable, and as a fresh vegetable it is not easy to transport, so its shelf life is short, which is the "bottleneck" of seriously restricting the industrialization of sea asparagus. There-fore, to break through the "bottleneck" and to promote the industrialization of sea asparagus, the most important solution is to research and develop the processed products of sea asparagus, with a longer storage time and easy for transportation.

At present, some processed products of sea asparagus have appeared in some markets around the world [7,27]. In general, the exploiting approaches for sea asparagus include at least as follows:

\subsection{Primarily Processed Products of Sea Asparagus}

Making pickle, by adding salt, sugar or vinegar, is the most common way for producing the primary level of sea asparagus products. These products are usually packaged in cans, ceramic pots (jars) or transparent plastic bags.

The primarily processed products of sea asparagus also include dehydrated vegetable (i.e. freeze dried vegetable), vegetable juice and vegetable powder, which can not only be eaten or used directly, but also provide raw material for other processed foods, such as vegetable noodle, vegetable steamed bread, vegetable dumplings and series of convenient snack foods.

\subsection{Deeply Processed Products of Sea Asparagus}

Currently, some deeply processed products of sea asparagus have already been sold in the markets worldwide, some products using sea asparagus as a main raw material, while others as an auxiliary material.

The deeply processed products containing sea as-paragus include at least nutrition tablets (chewable), mineral water, liquid seasoning, nutrition (diet) pills, nutrition (diet) granules, and sea asparagus capsules have already been in the market. 


\subsection{Producing Bio-Salt Is an Important Approach of Exploitation for Sea Asparagus}

Bio-salt means the salt is produced from biomass feedstock (plants, animals or microbes) by fermentation and other bio-technologies. The whole production processing involves no any chemical substances added and complies with the requirements of low sodium table salt and mineral-balanced table salt. It has beneficial biological effects and can promote human health [28,29].

The main characteristics of bio-salt are as follows: I. of biomass origin, esp. plants; II. Of naturally low-sodium salt with perfect balance of mineral elements; III. Being rich in organic nutrients and bioactive substances; IV. Without any chemical additives; V. Being helpful to the prevention and treatment of hypertension diabetes, kidney disease, cardiovascular disease and some other diseases. Therefore, bio-salt is an ideal table salt substitute for patients who have hypertension, cardiovascular disease, kidney disease, stroke and diabetes. It is believed that bio-salt will lead a green revolution in edible salt industry in the world.

Sea asparagus is an ideal resource for bio-salt, because, first, irrigation with sea water brings sea asparagus rich in sea minerals, which ensures a high efficiency of bio-salt producing; second, sea asparagus contains unique polysaccharides and alkaloids, which ensures the nutritional and medicinal value of bio-salt; third, sea asparagus has a long history as a food source, which ensures bio-salt with no side effects. Therefore, to produce bio-salt is an important approach in terms of exploitation of sea asparagus $[28,29]$

\subsection{Producing Animal Feed Is an Important Direction of Exploitation for Sea Asparagus}

Sea asparagus is rich in nutrition and has important medicinal value, therefore, animal feed production is an important direction of utilization of sea asparagus [23, 30].

There are already some applications put into practice, first, directly adding crushed dried sea asparagus to the feed as a salt and nutrient supplement; second, fresh Sea asparagus after fermentation is used as animal feed additive. It can effectively improve animal immune system, which replaces or reduces the use of antibiotics; third, the residues after producing bio-salt and after extracting oil from seeds are excellent sources of feed protein.

\subsection{Producing New Vegetable Oil and Bio-Diesel from Sea Asparagus Seeds}

In tropical and subtropical regions, people can extract edible oil from the seeds of sea asparagus [1,7,26,27].
Moreover, seed oil of sea asparagus can also be used in cosmetic and skin-care products. In addition, the seeds of sea asparagus are rich in linoleic acid, which can be used to produce conjugated linoleic acid. The conjugated linoleic acid has magical medical effects on cardiovascular and cerebrovascular diseases, breast and ovarian cancers and it can also improve human immunity and help to lose weight [31].

In addition, using seed oil of sea asparagus to produce bio-diesel has drawn more and more attention of the world. Because sea asparagus can be irrigated with seawater, they can be grown at coastal beaches and deserts in a large scale in tropical and subtropical regions to provide feedstock for biodiesel. Obviously, to produce the bio-diesel from sea asparagus seed oil will effectively avoid the disadvantages of growing traditional energy plants in competition of food, fresh water and arable soils with human kind. This will be an important developing trend of bio-energy for the future in the world [27, $32,33]$.

\subsection{Other Industrial Uses of Sea Asparagus}

In history, sea asparagus was ever a traditional raw material for production of glass and soap, so the whole plant or residues of sea asparagus can be used as raw materials for daily chemical products, such as soap, shower lotion, tooth paste and series of skin-care and cosmetic products. It can not only pro-vide abundant marine minerals, trace elements, unique natural substances of anti-oxidation and skin whitening, but also improve the added value of the products so as to bring more benefits to the production enterprises [18-20,27].

\section{CONCLUSIONS}

Since sea asparagus can be grown on seashores, saline soils and desert and completely irrigated with seawater, spreading the cultivation of sea asparagus across the world has a significant ecological and social meaning with respect to solving the issues of the growing scarcity of fresh water and arable soils resources.

China has abundant saline land and seashore re-sources, cultivating sea asparagus in a large scale will be a significantly beneficial strategy. Currently, agricultural development and utilization of coastal beaches are mainly aquaculture, so appropriately combining mari-culture with seawater cultivation of sea asparagus will be a comprehensive approach for the future [7,27].

To sum up, there are some ways to develop and utilize sea asparagus, including fresh vegetable, pickle, biosalt, health-care products, animal feed, vegetable oil, biodiesel and skin-care products. It is believed that, through reasonable planning and overall arrangement, by the building of the product line of sea asparagus, the large-scale 
and industrial development of sea asparagus will be realized in the near future.

\section{ACKNOWLEDGEMENTS}

This work was supported by the Hebei Provincial Scientific and Technology Development Projects Fund (No. 07220602D), the Shandong Provincial Scientific and Technology Development Projects Fund (No: 2011YD10012) and the Shandong Provincial Technical Innovation Projects Fund (No. 201211901027).

\section{REFERENCES}

[1] Glenn, E.P., O’Leary, J.W., Watson, M.C., et al. (1991) Salicornia bigelovii Torr.: An oilseed halophyte for seawater irrigation. Science, 251, 1065-1067. http://dx.doi.org/10.1126/science.251.4997.1065

[2] Rozema, J. and Flowers, T. (2008) Ecology: Crops for a Salinized World. Science, 322, 1478-1480. http://dx.doi.org/10.1126/science.1168572

[3] Zerai, D.B., Glenn, E.P., Chatervedi, R., et al (2010) Potential for the improvement of Salicornia bigelovii through selective breeding. Ecological Engineering, 36, 730-739. http://dx.doi.org/10.1016/j.ecoleng.2010.01.002

[4] Glenn, E.P., Brown, J.J., O’Leary, J.W., et al. (1998) Irrigating crops with seawater. Scientific American, 8, 76-81. http://dx.doi.org/10.1038/scientificamerican0898-76

[5] Ventura, Y. and Sagi, M. (2013) Halophyte crop cultivation: The case for Salicornia and Sarcocornia. Environmental and Experimental Botany, 92, 144-153. http://dx.doi.org/10.1016/j.envexpbot.2012.07.010

[6] Lu, Z. Hodges, R.M., Mota-Urbina, C., et al. (2001) Nutrient constituents of salicornia (Salicornia bigelovii Torr.): A seawater-irrigated new green vegetable. Hortscience, 36, 484.

[7] Feng, L., Wang, L. and Zhao, S. (2011) Research progress and utilization of sea asparagus irrigated by seawater. Shandong Agricultural Sciences, 43, 94-97.

[8] Kadereit, G., Ball, P., Beer, S., et al. (2007) A taxonomic nightmare comes true: phylogeny and biogeography of glassworts (Salicornia L., Chenopodiaceae). Taxon, 56, 1143-1170. http://dx.doi.org/10.2307/25065909

[9] Katschnig, D., Broekman, R. and Rozema J. (2013) Salt tolerance in the halophyte Salicornia dolichostachya Moss: Growth, morphology and physiology. Environmental and Experimental Botany, 92, 32-42. http://dx.doi.org/10.1016/j.envexpbot.2012.04.002

[10] Yong., C. J., Jong, H.A., Song, M.C., et al. (2002) Studies on pharmaological effects of Glasswort (Salicornia herbacea L.). Korean Journal of Medicinal Crop Science, 10, 93-99.

[11] Im, S., Kim, G.W. and Lee, C.K. (2003) Immunomodulatory activity of Salicornia herbacea L. components. Nat. Prod. Sci., 9, 273-277.

[12] Lee, Y.S., Lee, H.S., Shin, K.H., et al. (2004) Constituents of the Halophyte Salicornia herbacea. Archives of Pharmacal Research, 27, 1034-1036.

\section{http://dx.doi.org/10.1007/BF02975427}

[13] Chung, Y.C., Chun, H.K., Yang, J.Y., et al. (2005) Tungtungmadic Acid, a Novel Antioxidant, from Salicornia herbacea. Archives of Pharmacal Research, 28, 10341036. http://dx.doi.org/10.1007/BF02972972

[14] Im, S.A., Kim, J. and Lee, C.K. (2006) Immunomodulatory activity of polysaccharides isolated from Salicornia herbacea. International Immunopharmacology, 6, 1451-1458. http://dx.doi.org/10.1016/j.intimp.2006.04.011

[15] Sang, H.P., Sung, K.K., Jin, G.C., et al. (2006) Salicornia herbacea prevent high fat diet-induced hyperglycemia and hyperlipidemia in ICR mice. Archives of Pharmacal Research, 29, 256-264. http://dx.doi.org/10.1007/BF02969402

[16] Jang, H.S., Kim, K.R., Choi S.W., et al. (2007) Antioxidant and antithrombus activities of enzyme-treated Salicornia herbacea extracts. Annals of Nutrition \& Metabolism, 51, 119-125. http://dx.doi.org/10.1159/000100826

[17] Hwang, J.Y., Lee, S.K., Jo, J.R., et al. (2007) Hypolipidemic effect of Salicornia herbacea in animal model of type 2 diabetes mellitus. Nutrition Research and Practice, 1, 371-375. http://dx.doi.org/10.4162/nrp.2007.1.4.371

[18] Sung, J.H., Park, S.H., Seo, D.H., et al. (2009) Antioxidative and skin-whitening effect of an aqueous extract of Salicornia herbacea. Bioscience, Biotechnology, and Biochemistry, 73, 552-556. http://dx.doi.org/10.1271/bbb.80601

[19] Kim, Y.A., Kong, C.S., Young, R.U., et al. (2009) Evaluation of Salicornia herbaceae as a potential antioxidant and anti-inflammatory Agent. Journal of Medicinal Food, 12, 661-668. http://dx.doi.org/10.1089/jmf.2008.1072

[20] Rhee, M.H., Park, H.J. and Cho, J.Y. (2009) Salicornia herbacea: Botanical, chemical and parmacological review of halophyte marsh plant. Journal of Medicinal Plants Research, 3, 548-555.

[21] Hwang, Y.P., Yun, Y.J., Chun, H.K., et al. (2009) Protective mechanisms of 3-caffeoyl, 4-dihydrocaffeoyl quinic acid from Salicornia herbacea against tert-butyl hydroperoxide-induced oxidative damage. Chemico-Biological Interactions, 181, 366-376.

http://dx.doi.org/10.1016/j.cbi.2009.07.017

[22] Ryu, D.S., Kim, S.H. and Lee, D.S. (2009) Anti-proliferative effect of polysaccharides from Salicornia herbacea on induction of G2/M arrest and apoptosis in human colon cancer cells. Journal of Microbiology and Biotechnology, 19, 1482-1489.

[23] Sarker, S.K., Park, S.R., Kim, G.M., et al. (2010) Hamcho (Salicornia herbacea) with probiotics as alternative to antibiotic for broiler production. Journal of Medicinal Plants Research, 4, 415-420.

[24] Hwang, Y.P., Yun, H.J., Choi J.H., et al. (2010) 3-caffeoyl, 4-dihydrocaffeoyl quinic acid from Salicornia herbacea inhibits tumor cell invasion by regulating protein kinase $\mathrm{C}-\delta$-dependent matrix metalloproteinase-9 expression. Toxicology Letters, 198, 200-209. http://dx.doi.org/10.1016/j.toxlet.2010.06.018

[25] Kang, S., Kim, D., Lee B.H., et al. (2011) Antioxidant 
properties and cytotoxic effects of fractions from glasswort (Salicornia herbacea) seed extracts on human intestinal cells. Food Science and Biotechnology, 20, 115-122. http://dx.doi.org/10.1007/s10068-011-0016-7

[26] Anwar, F., Bhanger, M.I., Nasir M.K.A., et al. (2002) Analytical characterization of Salicornia bigelovii seed oil in Pakistan. Journal of Agricultural and Food Chemistry, 40, 4210-4214. http://dx.doi.org/10.1021/jf0114132

[27] Feng, L. and Wen, L. (2009) The development and utilization of Salicornia bigelovii. Journal of Salt and Chemical Industry, 38, 38-42.

[28] Feng, L., Duan, J.J. and Li, H.J. (2008) Preliminary review of biomass edible Salt. Journal of Salt and Chemical Industry, 37, 39-42.

[29] Feng, L., Wen, L. and Su, B. (2009) On edible bio-salt. In: Sha, Z.L., Ed., The 9th International Symposium on Salt, Gold Wall Press, Beijing, 1466-1467.
[30] Attia, F.M., Alsobayel, A.A., Kriadees, M.S., et al. (1997) Nutrient composition and feeding value of Salicornia bigelovii Torr meal in broiler diets. Animal Feed Science and Technology, 65, 257-263.

http://dx.doi.org/10.1016/S0377-8401(96)01074-7

[31] Park, Y, Albright, K.J., Liu, W., et al. (1997) Effect of conjugated linoleic acid on body composition in mice. Lipids, 32, 853-858. http://dx.doi.org/10.1007/s11745-997-0109-x

[32] Feng, L. (2008) Halophytes promising for biomass energy resources in China. Journal of Biotechnology, 136S, S271.

[33] Bailis, R. and Yu, E. (2012) Environmental and social implications of integrated seawater agriculture systems producing Salicornia bigelovii for biofuel. Biofuels, 3, 555-574. http://dx.doi.org/10.4155/bfs. 12.50 